\title{
HUBUNGAN WAKTU TUNGGU PELAYANAN TERHADAP TINGKAT KEPUASAN PASIEN DI POLIKLINIK KEBIDANAN DAN KANDUNGAN RSUD KOTA SURAKARTA
}

\section{THE RELATIONSHIP BETWEEN SERVICE WAITING TIME ON PATIENT SATISFACTION LEVEL IN OBSTETRIC AND GYNECOLOGY POLYCLINIC OF SURAKARTA DISTRICT GENERAL HOSPITAL}

\author{
Muthiah Rissa Pratiwi ${ }^{1)}$, Fakhrudin Nasrul Sani ${ }^{2}$ \\ ${ }^{1}$ D3 Keperawatan, STIKes Kusuma Husada Surakarta \\ email: msicha27@gmail.com \\ ${ }^{2}$ D3 Keperawatan, STIKes Kusuma Husada Surakarta \\ email: fakhrudin_ns@ymail.com
}

\begin{abstract}
Abstrak
Waktu tunggu pelayanan merupakan masalah yang sering menimbulkan keluhan pasien di beberapa Rumah Sakit. Lamanya waktu tunggu pasien mencerminkan bagaimana Rumah Sakit mengelola komponen pelayanan yang disesuaikan dengan situasi dan harapan pasien. Pelayanan yang baik dan bermutu tercermin dari pelayanan yang ramah, capat, nyaman. Menunggu dalam waktu yang lama akan menyebabkan ketidakpuasan. Kepuasan merupakan suatu tingkat perasaan yang timbul sebagai akibat dari kinerja pelayanan kesehatan yang di peroleh setelah pasien membandingkan dengan apa yang diharapkan. Penelitian ini menggunakan desain penelitian observasional analitik dengan pendekatan cross sectional yang dilakukan di Poliklinik Kebidanan dan Kandungan RSUD Kota Surakarta. Teknik pengambilan sampel menggunakan purposive sampling dengan jumlah responden sebanyak 86 responden. Uji analisis dengan uji spearman rank dengan tingkat kemaknaan $p<0,05$. Hasil penelitian waktu tunggu pelayanan $<60$ menit $(61,6 \%)$ dan kepuasan pasien kategori puas (91,9\%). Uji spearman rank p value sebesar 0,029 <0,05 sehingga terdapat hubungan antara waktu tunggu pelayanan dengan tingkat kepuasan pasien di Poliklinik kebidanan dan Kandungan RSUD Kota Surakarta. Waktu tunggu pelayanan yang singkat sangat dibutuhkan dalam pelayanan untuk menciptakan kepuasan pada pasien terhadap pelayanan di Rumah Sakit. Bagi petugas kesehatan diharapkan lebih komitmen dan disiplin waktu dalam memberikan Pelayanan dan sesuai dengan jadwal yang telah ditetapkan.
\end{abstract}

Kata Kunci: Waktu tunggu pelayanan, kepuasan pasien.

\begin{abstract}
The waiting time of service is a problem that often leads to patient complaints in several hospitals. The duration of patient waiting time reflects how hospital manages service components which are suitable to the patient's situation and expectation. Good service quality is reflected from friendly service, fast, and comfortable. Waiting in a long time will lead to the dissatisfaction. Satisfaction is a state of feeling that arises as a result of the health service performance which is obtained after patients compare it with their expectation. This research used analytic observational design with cross sectional approach which was done in the Obstetrics and Gynecology Department of RSUD Surakarta. The sampling technique used was purposive sampling which consisted of 86 respondents. The data were analyzed by using Spearman rank test with a significance level of $p<0.05$. The results of the research showed that service waiting time of service was <60 minutes $(61.6 \%)$ and patient satisfaction in satisfied category was $91.9 \%$. Spearman test rank $p$ value was $0.029<0.05$, so there is a relation between waiting time of service and patients' satisfaction at obstetrics and gynecology department of RSUD Surakarta. A short wait time of service isvery needed in the hospital servicesto raise patients' satisfaction toward the services in a hospital. Medical staffs are expected to have more commitment and discipline of time in providing services in accordance with a predetermined schedule.
\end{abstract}

Keywords: Waiting time of service, patient satisfaction. 


\section{PENDAHULUAN}

Berdasarkan Undang-undang kesehatan no 44 tahun 2009, Rumah Sakit merupakan institusi pelayanan kesehatan perorangan secara paripurna yang menyediakan pelayanan Rawat Inap, Rawat Jalan dan Gawat Darurat dan sarana prasarana lainnya. Instalasi Rawat Jalan (IRJ) merupakan unit fungsional yang menangani penerimaan pasien di Rumah Sakit, baik yang berobat Rawat Jalan atau yang akan dirawat di Rumah Sakit. Perawatan di Rawat Jalan pertama dilakukan di loket karcis sampai selesai pemberian resep di Apotik. Sarana dan fasilitas Rawat Jalan akan memberikan dampak terhadap kualitas pelayanan terhadap masyarakat, sarana yang memadai dan akses yang mudah dan fasilitas Rumah Sakit yang lengkap akan memberikan pengaruh terhadap kepuasan pasien pengguna jasa layanan kesehatan (Trarintya, 2011).

Kepuasan pasien salah satunya diduga dipengaruhi oleh waktu tunggu pelayanan. Waktu tunggu pelayanan merupakan masalah yang sering menimbulkan keluhan pasien dibeberapa Rumah Sakit. Lamanya waktu tunggu pasien mencerminkan bagaimana Rumah Sakit mengelola komponen pelayanan yang disesuaikan dengan situasi dan harapan pasien. Pelayanan yang baik dan bermutu tercermin dari pelayanan yang ramah, cepat, nyaman (Utami, 2015).

Menurut Menkes RI Nomor129/Menkes/SK/ 11/2008 tentang standar pelayanan minimal Rumah Sakit disebutkan bahwa standar waktu tunggu pelayanan rawat jalan $\leq 60$ menit, jika waktu tunggu $\geq 60$ menit pelayanan Rawat Jalan tersebut dikatakan lama atau tidak sesuai dengan standar yang telah ditetapkan. Waktu tunggu pelayanan ini sering diabaikan dan tidak sesuai dengan standar yang ada. Tiga faktor penyebab utama lamanya waktu tunggu pelayanan pasien yaitu: lamanya waktu pendaftaran di loket, terbatasnya jumlah dokter, terbatasnya staf pelayanan kesehatan lainnya (Abdulah, 2005).

Sebagian besar masyarakat mengeluh dan merasa tidak puas dengan pelayanan yang diberikan oleh Rumah Sakit, baik dari segi pemeriksaan yang kurang diperhatikan oleh petugas kesehatan, keterampilan petugas, sarana atau fasilitas yang kurang memadai, serta waktu tunggu yang lama untuk mendapatkan pelayanan. Rendahnya kinerja pelayanan akan membangun citra buruk pada Rumah Sakit, dimana pasien akan merasa tidak puas akan menceritakan kepada rekan-rekannya, begitu sebaliknya semakin tinggi kinerja pelayanan yang diberikan akan menjadi nilai plus bagi Rumah Sakit, dalam hal ini pasien akan puas terhadap pelayanan yang diberikan (Pohan, 2007).

Berdasarkan studi pendahuluan jumlah kunjungan pasien di Poliklinik Kebidanan dan Kandungan RSUD Kota Surakarta pada bulan April 2016 sebanyak 573 orang dengan pasien obstetri dan pasien ginekologi. Hasil observasi rata-rata pasien Poliklinik Kebidanan dan Kandungan adalah Poliklinik yang memiliki waktu tunggu pelayanan paling lama yaitu lebih dari 60 menit dibandingkan dengan Poliklinik lainnya.

Hasil wawancara dengan tiga orang pasien, dua orang pasien BPJS (66\%) mengatakan lambatnya pelayanan, tidak puas dengan pelayanan kesehatan yang diberikan, harus meninggalkan pekerjaan rumah dan anak, merasa lelah terlalu lama menunggu, kurang lebih sudah dari jam 7.30 di Rumah Sakit langsung mengambil nomor antrian lalu mendaftar dan melengkapi administrasi di loket, kemudian menunggu di ruang tunggu Poliklinik Kebidanan dan Kandungan \pm 30 menit di panggil untuk dilakukan pemeriksan tensi, ditanyakan keluhan (anamnese) oleh bidan setelah dilakukan pemeriksaan oleh bidan diajurkan untuk menunggu di ruang tunggu Poliklinik sampai ada panggilan untuk dilakukan pemeriksaan oleh dokter Spesialis Kandungan, setelah \pm 4 jam menunggu baru dipanggil untuk dilakukan pemeriksaan oleh dokter Spesialis. Satu orang pasien Umum (34\%) mengatakan puas dengan pelayanan, tidak lama menunggu, dari jam 9.00 di Rumah Sakit, mengambil nomor antrian lalu mendaftar dan melengkapi administrasi di loket, kemudian menunggu di ruang tunggu Poliklinik Kebidanan dan Kandungan \pm 15 menit lalu dipanggil untuk dilakukan pemeriksaan tensi, ditanyakan keluhan oleh bidan (anamnese) dan langsung mendapatkan pelayanan dari bidan untuk dilakukan perawatan luka operasi.

Berdasarkan latar belakang tersebut peneliti merasa tertarik untuk melakukan penelitian tentang hubungan waktu tunggu pelayanan terhadap tingkat kepuasan di Poliklinik Kebidanan dan Kandungan RSUD Kota Surakarta.

\section{METODE PENELITIAN}

Metode penelitian yang digunakan merupakan penelitian kuantitatif observasional analitik dengan pendekatan cross sectional. Penelitian ini dilakukan di Poliklinik Kebidanan dan Kandung- 
an RSUD Kota Surakarta pada tanggal 5september sampai dengan 24 september 2016. Sampel dalam penelitian ini berjumlah 86 sampel. Teknik pengambilan sampel menggunakan purposive sampling. Kriteria inklusi yang digunakan dalam penelitian ini sebagai berikut:

1. Pasien yang berkunjung ke Poliklinik Kebidanan dan Kandungan.

2. Pasien yang bisa membaca.

3. Pasien yang bersedia untuk menjadi responden.

Kriteria eksklusi yang digunakan dalam penelitian ini sebagai berikut: Pasien yang datang ke Poliklinik Kebidanan dan Kandungan, kemudian terdapat indikasi untuk rawat inap.

Instrumen pengumpulan data menggunakan kuesioner untuk mendapatkan data kepuasan pasien dan lembar observasi untuk mendapatkan data waktu tunggu pelayanan di Poliklinik Kebidanan dan Kandungan RSUD Kota Surakarta. Uj analisis data yaitu univariat untuk menjelaskan atau mendeskripsikan karakteristik setiap variabel penelitian dengan menggunakan distribusi frekuensi dan analisis bivariat untuk mengetahui hubungan keterkaitan dua variabel dengan menggunakan uji Spearman Rank.

\section{HASIL DAN PEMBAHASAN}

Tabel 1. Distribusi Frekuensi Umur Responden di Poliklinik Kebidanan dan Kandungan RSUD Kota Surakarta

$$
\mathrm{n}=86
$$

\begin{tabular}{lcc}
\hline Umur (Tahun) & $\begin{array}{c}\text { Frekuensi } \\
\text { (f) }\end{array}$ & $\begin{array}{c}\text { Presentase } \\
(\%)\end{array}$ \\
\hline$<20$ & 5 & 5,8 \\
$20-35$ & 62 & 72,1 \\
$>35$ & 19 & 22,1 \\
Total & 86 & 100 \\
\hline
\end{tabular}

Pada tabel 1 menunjukan karakteristik responden berdasarkan umur 62 orang $(72,1 \%)$ berumur 20-35 tahun, 19 orang ( 22,1\%) berumur $>35$ tahun dan 5 orang $(5,8 \%)$ berumur $<20$ tahun.
Tabel 2. Distribusi Frekuensi Pendidikan Responden di Poliklinik Kebidanan dan Kandungan RSUD Kota Surakarta $\mathrm{n}=86$

\begin{tabular}{lcc}
\hline \multicolumn{1}{c}{ Pendidikan } & Frekuensi (f) & $\begin{array}{c}\text { Persentase } \\
(\%)\end{array}$ \\
\hline SD & 7 & 8,1 \\
SMP/Sederajad & 13 & 15,1 \\
SMU/Sederajad & 60 & 69.8 \\
Akademi/Diploma & 4 & 4,7 \\
Sarjana & 2 & 2,3 \\
Total & 86 & 100.0 \\
\hline
\end{tabular}

Pada tabel 2 dapat diketahui bahwa pendidikan terakhir responden sebagian besar berpendidikan SMA 60 orang $(69,8 \%)$, berpendidikan SMP 13 orang $(15,1 \%)$, berpendidikan SD 7 orang $(8,1 \%)$, berpendidikan Diploma 4 orang $(4,7 \%)$ dan berpendidikan sarjana 2 orang $(2,3 \%)$.

Tabel 3. Distribusi Frekuensi Pekerjaan Responden di Poliklinik Kebidanan dan Kandungan RSUD Kota Surakarta $\mathrm{n}=86$

\begin{tabular}{lcc}
\hline \multicolumn{1}{c}{ Pekerjaan } & $\begin{array}{c}\text { Frekuensi } \\
(\mathrm{f})\end{array}$ & $\begin{array}{c}\text { Persentase } \\
(\%)\end{array}$ \\
\hline Karyawan Swasta & 22 & 25,6 \\
Wiraswasta & 6 & 7,0 \\
PNS & 6 & 7,0 \\
Tidak Bekerja / & 50 & 58,1 \\
Ibu Rumah Tangga & & \\
Lain-lain & 2 & 2.3 \\
Total & 86 & 100.0 \\
\hline
\end{tabular}

Pada tabel 3 dapat diketahui 50 orang $(58,1 \%)$ tidak bekerja/ ibu rumah tangga, 22 orang $(25,6 \%)$ pekerjaan karyawan swasta, 6 orang $(7,0 \%)$ pekarjaan wiraswasta, 6 orang $(7,0 \%)$ pekerjaan PNS dan 2 orang $(2,3 \%)$ pekerjaan lain-lain. 
Tabel 4. Distribusi Frekuensi Kunjungan Responden di Poliklinik Kebidanan dan Kandungan RSUD Kota Surakarta

$$
\mathrm{n}=86
$$

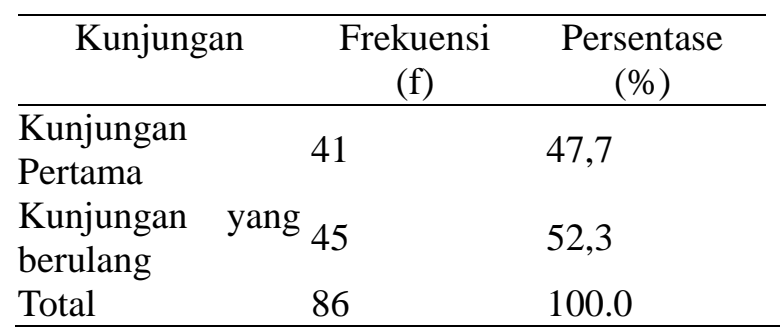

Pada tabel 4 dapat diketahui bahwa sebagian besar responden adalah kumjungan berulang sebanyak 45 orang $(52,3 \%)$ dan Kunjungan pertama Responden sebanyak 41 orang $(47,7 \%)$.

Tabel 5. Distribusi Frekuensi Waktu Tunggu Pelayanan Responden di Poliklinik Kebidanan dan Kandungan RSUD Kota Surakarta

$$
\mathrm{n}=86
$$

\begin{tabular}{lcl}
\hline \multicolumn{1}{c}{$\begin{array}{c}\text { Waktu Tunggu } \\
\text { pelayanan }\end{array}$} & $\begin{array}{c}\text { Frekuensi } \\
(\mathrm{f})\end{array}$ & $\begin{array}{c}\text { Persentase } \\
(\%)\end{array}$ \\
\hline$<60$ menit & 53 & 61,6 \\
$>60$ menit & 33 & 31,4 \\
Total & 86 & 100.0 \\
\hline
\end{tabular}

Pada tabel 5 dapat diketahui bahwa sebagian besar waktu tunggu pelayanan responden $<60$ menit sebanyak 53 orang $(61,6 \%)$, dan waktu tunggu pelayanan responden $>60$ menit sebanyak 33 orang $(31,4 \%)$.

Tabel 6. Distribusi Frekuensi Pengguna Jaminan di Poliklinik Kebidanan dan Kandungan RSUD Kota Surakarta

$$
\mathrm{n}=86
$$

\begin{tabular}{lll}
\hline \multicolumn{1}{c}{ Jaminan } & \multicolumn{1}{c}{$\begin{array}{c}\text { Frekuensi } \\
\text { (f) }\end{array}$} & \multicolumn{1}{c}{$\begin{array}{c}\text { Persentase } \\
(\%)\end{array}$} \\
\hline BPJS & 61 & 70,9 \\
Umum & 24 & 27,9 \\
Pengguna Asuransi & 1 & 1,2 \\
Total & 86 & 100.0 \\
\hline
\end{tabular}

Pada tabel 6 dapat diketahui bahwa sebagian besar responden pengguna asuransi BPJS sebanyak 61 orang $(70,9 \%)$, Pembayaran umum sebesar 24 orang $(27,9 \%)$ dan pengguna asuransi sebanyak 1 orang $(1,2 \%)$.
Tabel 7. Distribusi Frekuensi Kepuasan Layanan Responden di Poliklinik Kebidanan dan Kandungan RSUD Kota Surakarta

$$
\mathrm{n}=86
$$

\begin{tabular}{lll}
\hline Kepuasan Layanan & \multicolumn{1}{c}{$\begin{array}{c}\text { Frekuensi } \\
\text { (f) }\end{array}$} & $\begin{array}{c}\text { Persentase } \\
(\%)\end{array}$ \\
\hline Kurang Puas & 7 & 8,1 \\
Puas & 79 & 91,9 \\
Total & 86 & 100.0 \\
\hline
\end{tabular}

Pada tabel 7 dapat diketahui bahwa sebagian besar responden sebanyak 79 orang $(91,9 \%)$ menunjukan rasa puas, dan 7 orang $(8,1 \%)$ menunjukan rasa kurang puas.

Hasil dari penelitian yang dilakukan di Poliklinik Kebidanan dan Kandungan RSUD Kota Surakarta yang berjumlah 86 responden didapatkan hasil penelitian berdasarkan umur sebagian besar responden berumur 20-35 tahun (72,1\%). Hasil penelitian ini sesuai dengan penelitian Utami (2015), yang dilakukan terhadap 30 orang pasien di Rawat Jalan sebuah Rumah Sakit di Kota Solo, mendapatkan rata-rata umur pasien 20-35 tahun. Menurut Notoatmodjo (2010), menunjukkan bahwa usia seseorang akan memengaruhi daya tangkap dan pola pikir seseorang terhadap informasi yang diberikan. Semakin bertambah usia maka daya tangkap dan pola pikir seseorang semakin berkembang. Peneliti berpendapat bahwa responden yang sebagian besar usia dewasa pertengahan, mempunyai kemampuan untuk memberikan penilaian secara obyektif terhadap pengalaman tentang waktu tunggu pelayanan.

Berdasarkan tingkat pendidikan, pada penelitian ini sebagian besar responden berpendidikan tinggi yaitu SMA $(69,8 \%)$. Penelitian Kusdariah (2014), mendapatkan hasil penelitian yang sama dengan penelitian ini dimana tingkat pendidikan responden sebagian besar adalah pendidikan tinggi adalah SMA. Hal ini menunjukan semakin tinggi pendidikan seseorang semakin tinggi pula pengetahuannya. Menurut Nursalam (2013), bahwa latarbelakang pendidikan seseorang akan memengaruhi kemampuan berpikir seseorang, dengan pendidikan seseorang akan dapat meningkatkan kematangan intelektual sehingga dapat membuat keputusan dalam bertindak dan memberikan penilaian tertentu.

Berdasarkan status pekerjaan pada penelitian ini sebagian responden bekerja sebagai Ibu rumah tangga $(58,1 \%)$. Hasil penelitian Dewi 
(2014), menemukan sebagian responden bekerja sebagai karyawan swasta.

Berdasarkan kunjungan, pada penelitian ini ditemukan sebagian besar responden adalah kunjungan berulang $(52,3 \%)$. Menurut peneliti responden dengan kunjungan berulang lebih merasa puas dengan pelayanan kesehatan.

Berdasarkan pengguna jaminan, pada penelitian ini sebagian besar responden adalah pengguna BPJS $(70,9 \%)$. Penelitian ini sama dengan penelitian Utami (2015), yang dilakukan terhadap 51 orang pasien di Rawat Jalan sebuah Rumah Sakit di Kota Solo ditemukan pengguna asuransi kesehatan terbanyak adalah $(47,1 \%)$. Peneliti berpendapat bahwa pengguna jaminan tidak berpengaruh terhadap kepuasan pasien.

\section{Kepuasan pasien di Poliklinik Kebidanan dan Kandungan RSUD Kota Surakarta}

Hasil kepuasan pasien secara umum berdasarkan tabel 7 menyatakan puas, (91,9\%), kurang puas $(8,1 \%)$, hasil penelitian ini menunjukkan bahwa di Poliklinik Kebidanan dan Kandungan telah memberikan pelayanan yang baik. Kepuasan pasien terhadap pelayanan kesehatan di Poliklinik Kebidanan dan Kandungan RSUD Kota Surakarta, disebabkan karena petugas di Poliklinik Kebidanan dan Kandungan memberikan pelayanan dengan cepat.

Penelitian ini sesuai dengan penelitian Kusdariah (2014), yang dilakukan terhadap 36 responden pada sebuah Puskesmas di kota Surabaya ditemukan 17 responden $(47,2 \%)$ merasa puas, 14 responden $(38,9 \%)$ menyatakan cukup puas dan 5 responden $(13,9 \%)$ menyatakan kurang puas.

Kepuasan merupakan perasaan senang ataupun kecewa seseorang yang munculsetelah perbandingan antara presepsi atau kesan terhadap kinerja atau hasil suatu produk dan harapanharapannya (Nursalam, 2013). Tingkat kepuasan pasien didukung oleh 5 faktor yaitu tangibles, reliability, responsiveness, assurance dan empathy. Kelima faktor ini merupakan faktor yang dapat mempengaruhi rasa puas pasien yang harus diterapkan perawat dalam pemberian pelayanan asuhan keperawatan.

Hal ini sesuai dengan penelitian yang dilakukan oleh Kuntari (2013), dimana dari hasil analisisnya tentang penentu kepuasan pasien di sebuah Rumah Sakit di Kota Yogyakarta mengatakan bahwa kepuasan pasien dipengaruhi oleh 5 faktor tingkat kepuasan dan dalam penelitiannya reliability merupakan faktor yang terpenting, namun ke 5 faktor ini harus diterapkan perawat dengan baik.

Peneliti berpendapat bahwa kepuasan adalah perasaan senang terhadap pelayanan yang diberikan dimana pelayanan tersebut sesuai dengan harapan atau bahkan melebihi harapan pasien. Hasil penelitian diatas dapat disimpulkan bahwa sebagian besar pasien merasa puas dengan pelaksanaan pelayanan keperawatan di Poliklinik Kebidanan dan Kandungan RSUD Kota Surakarta, karena pelayanan sudah sesuai dengan harapan pasien.

\section{Waktu tunggu pelayanan pasien di Poliklinik Kebidanan dan Kandungan RSUD Kota Surakarta.}

Hasil penelitian berdasarkan tabel 4.5 menunjukan rata-rata waktu tunggu pelayanan yang dinilai oleh 86 responden di Poliklinik Kebidanan dan Kandungan RSUD Kota Surakarta hasil sebagian besar waktu tunggu pelayanan pasien $<60$ menit $(61,6 \%)$ dan $>60$ menit (33\%). Hasil penelitian ini menunjukan bahwa petugas di Poliklinik Kebidanan dan Kandungan RSUD Kota Surakarta memberikan pelayanan secara cepat. Adapun faktor yang mendukung petugas memberikan pelayanan dengan cepat adalah karena pasien yang datang hanya mengganti balutan luka sehingga tidak perlu harus menunggu dokter.

Menurut Menkes RI Nomor.129/ Menkes/ SK/ 11 /2008 tentang standar pelayanan minimal Rumah Sakit disebutkan bahwa standar waktu tunggu pelayaan Rawat Jalan $\leq 60$ menit, jika waktu tunggu $\geq 60$ menit pelayanan Rawat Jalan tersebut dikatakan lama atau tidak sesuai dengan standar yang ditetapkan. Tingginya penilaian penilaian waktu tunggu $<60$ menit menurut responden dalam penelitian ini merupakan suatu hal yang positif yang dapat memicu peningkatan pelayanan di Poliklinik Kebidanan dan Kandungan RSUD Kota Surakarta.

\section{Analisis Bivariat \\ Analisa bivariat digunakan untuk menge- tahui apakah ada hubungan yang signifikan antara dua variabel atau bisa juga digunakan untuk mengetahui apakah ada perbedaan yang signifikan antara dua atau lebih kelompok (sampel). Hasil uji spearman rank dapat mengetahui ada tidaknya hubungan yang}


bermakna secara statistik. Hasil analisis bivariat sebagai berikut.

Tabel 8. Hasil analisis bivariat hubungan waktu tunggu pelayanan terhadap tinggkat kepuasan pasien di Poliklinik Kebidanan dan Kandungan RSUD Kota Surakarta

\begin{tabular}{cccccc}
\hline $\begin{array}{c}\text { Waktu } \\
\text { tunggu } \\
\text { pelayanan }\end{array}$ & Puas & $\begin{array}{c}\text { Kurang } \\
\text { puas }\end{array}$ & Total & $\mathrm{R}$ & $\begin{array}{c}\mathrm{P} \\
\text { value }\end{array}$ \\
\hline $\begin{array}{c}\text { Cepat } \\
(<60\end{array}$ & $\begin{array}{c}46 \\
(86,8 \%)\end{array}$ & $\begin{array}{c}7 \\
(13,2 \%)\end{array}$ & $\begin{array}{c}53 \\
(100 \%)\end{array}$ & 0,23 & 0,02 \\
$\begin{array}{c}\text { menit }) \\
\text { Lama }\end{array}$ & 33 & $0(0 \%)$ & 33 & & \\
$\begin{array}{c}(>60 \\
\text { menit })\end{array}$ & $(100 \%)$ & & $(100 \%)$ & & \\
Total & 79 & 7 & 86 & & \\
& $(91,9 \%)$ & $(8,1 \%)$ & $(100 \%)$ & & \\
\hline
\end{tabular}

Berdasarkan tabel 8 di atas hasil analisis hubungan waktu tunggu pelayanan terhadap tingkat kepuasan pasien diperoleh bahwa waktu tunggu pelayanan cepat $(<60$ menit $)$ memberikan kepuasan pasien tinggi sebanyak 46 responden $(86,8 \%), 7$ orang $(13,2 \%)$ merasa kurang puas. waktu tunggu pelayanan lama (>60 menit) menunjukan sebanyak 33 orang $(100 \%)$ merasa puas dan tidak ada yang kurang puas.

Hasil uji statistik Spearman diperoleh nilai $\mathrm{r}$ hitung sebesar 0,23 dengan nilai $r=0,02$ ( $p$ value 0,05 ) yang berarti secara statistik mempunyai makna bahwa hubungan waktu tunggu pelayanan dengan tingkat kepuasan pasien di Poliklinik Kebidanan dan Kandungan RSUD Kota Surakarta menunjukan arah hubungan yang positif dengan tingkat hubungan yang rendah.

Hasil penelitian ini menunjukkan adanya kecenderungan semakin cepat waktu tunggu pelayanan semakin meningkat semakin meningkat kepuasan pasien.

Hasil penelitian ini didukung oleh penelitian Utami (2015), di sebuah Rumah Sakit di Kota Solo menemukan hasil bahwa $80 \%$ pasien sangat puas dengan waktu tunggu. Hasil perhitungan chi square diperoleh sig $(0,000)$ berarti $<0,01$ maka Ho ditolak dan Ha diterima artinya waktu tunggu pelayanan rawat jalan mempunyai hubungan yang signifikan dengan kepuasan pasien rawat jalan. Hasil ini didukung oleh penelitian Dewi (2014), di ruang tunggu pendaftaran sebuah Rumah Sakit di Kota Sukoharjo menemukan 41 responden dengan waktu tunggu pendaftaran cepat sebagian besar merasa puas dengan pelayanan. Hasil uji statistik didapatkan nilai uji chi square sebesar $\mathrm{p}=0,000(\mathrm{p}<0,05)$, yang berarti Ho ditolak, jadi ada hubungan yang signifikan antara waktu tunggu pendaftaran dengan kepuasan pasien.

Menurut Wijono (2008), mengatakan bahwa waktu tunggu pasien merupakan salah satu komponen yang potensial menyebabkan ketidakpuasan. Pasien akan menganggap pelayanan kesehatan tidak baik apabila sakitnya tidak sembuh, antri lama, dan petugas kesehatan tidak ramah meskipun profesional.

Peneliti berpendapat bahwa baik buruknya pelayanan kesehatan juga tergantung dari waktu yang diperlukan untuk mendapatkan pelayanan. Dari hasil penelitian diatas tentang waktu tunggu pelayanan dengan kepuasan pasien erat hubungannya karena perawat harus dapat dirasakan dan memberi dampak yang positif terhadap pasien sebagai penerima layanan kesehatan di Rumah Sakit jika waktu tunggu pelayanan yang diterima pasien cepat maka pasien akan merasa puas dan sebaliknya apabila waktu tunggu pelayanan lama maka pasien akan merasa tidak puas dan enggan menggunakan pelayanan kesehatan tersebut.

\section{SIMPULAN}

Berdasarkan hasil penelitian dan pembahasan, maka dapat diambil simpulan sebagai berikut :

1. Karakteristik pasien yang menjadi responden penelitian sebagian besar adalah berpendidikan tinggi yaitu SMA sebanyak 60 orang $(69,8 \%)$, rata-rata umur 20-35 tahun sebanyak 62 orang $(72,1 \%)$, bekerja sebagai Ibu rumah tangga sebanyak 50 orang $(58,1 \%)$, kunjungan berulang sebanyak 45 orang $(52,3 \%)$, serta pengguna jaminan BPJS sebanyak 61 orang (70,9\%).

2. Kepuasan di Poliklinik Kebidanan dan Kandungan RSUD Kota Surakarta mayoritas puas sebanyak 79 orang $(91,9 \%)$, dan kurang puas sebanyak 7 orang $(8,1 \%)$.

3. Rata-rata waktu tunggu pelayanan pasien di Poliklinik Kebidanan dan Kandungan RSUD Kota Surakarta mayoritas <60 menit sebanyak 53 orang $(61,6 \%)$

4. Terdapat hubungan antara waktu tunggu pelayanan dengan tingkat kepuasan pasien di Poliklinik Kebidanan dan Kandungan RSUD Kota Surakarta.Hasil uji statistik diperoleh 
nilai $\mathrm{r}$ hitung sebesar 0,235 dengan pvalue $=$ 0,029 . $<0,05$.

\section{REFERENSI}

Abdullah.M.H. 2005. Study On Outpatient's Waiting Time In Hospital University Kebangsaan Malaysia (HKM) Though The Siz Aignia Approach.

Dewi Aulia Utami (2014). Hubungan Waktu Tunggu Pendaftaran dengan Kepuasan Pasien di tempat Pendaftaran Pasien Rawatl Jalan (TPPRJ) RSUD Sukoharjo.

Kusdariah, Diyan Maulid. 2014. Correlation Service Time Efficiency With Satisfaction Of Patient in the Out Patient Unit Gedangan Centers.

Kuntari. T. 2013. Jurnal Anlisa Faktor Penentu Tingkat Kepuasan Pasien di Rumah Sakit PKU Muhamdiyah Bantul. Http://rac.uii. ac.id.uii-jurnal diakses pada tanggal 1 oktober 2016.

Notoatmodjo. S. 2010.Metode penelitian kesehatan. Jakarta: PT Rineka Cipta.

Nursalam. 2013. Manajement Keperawatan. Jakarta : Salemba Medika.

Pohan I. 2007. Jaminan Mutu Pelayanan Kesehatan.

Trarintya. 2011. Pengaruh Kualitas Pelayanan Terhadap Kepuasan dan Word of Mouth Pasien Rawat Jalan di Wing Amerta RSUD Sanglah Denpasar.

Utami, Yeni Tri. 2015. Hubungan Waktu Tunggu Rawat dengan Tingkat Kepuasan Pasien di RSU Asslam Gemolong.

Wijono, Djoko (2008). Manajemen Mutu Rumah Sakit dan Kepuasan Pasien Prinsip dan Praktik. Surabaya: CV. Duta Prima Airlanggaa. 


\title{
HUBUNGAN PELAYANAN KB IUD TERHADAP TINGKAT KEPUASAN AKSEPTOR KB IUD
}

\section{THE CORELATION OF THE IUD FAMILY PLANNING SERVICE WITH THE LEVEL OF SATISFACATION AT IUD ACCEPTORS}

\author{
Nevia Zulfatunnisa, Qurrota Ainy \\ Prodi DIII Kebidanan STIKES PKU Muhammadiyah Surakarta \\ email: Nevia.zulfa@gmail.com
}

\begin{abstract}
Abstrak
Pelayanan keluarga berencana bertujuan untuk meningkatkan kesejahteraan ibu serta anak melalui pengendalian kelahiran dan pengendalian pertumbuhan penduduk. Hasil studi pendahuluan didapatkan data seluruh akseptor KB IUD tahun 2015 IUD 86 orang. Hasil yang didapatkan 15 akseptor merasa puas dan 5 akseptor tidak puas dengan pelayanan KB IUD meliputi : tanggapan bidan, privasi, sikap bidan, dan konseling yang diberikan. Tujuan penelitian ini Untuk mengetahui hubungan pelayanan KB IUD terhadap tingkat kepuasan akseptor KB IUD. Metode penelitian ini menggunakan deskriptif analitik dengan pendekatan cross sectional. Populasi penelitian masyarakat Sangkrah yang menggunakan KB IUD dengan tekhnik sample menggunakan Non Random Sampling dengan metode quota sampling sejumlah 30 responden. Instrumen penelitian menggunakan quesioner. Analisa yang digunakan berupa spearman rank test pada signifikan 5\%..Hasil penelitian didapatkan mayoritas pelayanan yang baik sebanyak 63,3\%, dan minoritas pelayanan yang kurang $20 \%$, sedangkan pada mayoritas tingkat kepuasan yang puas sebanyak 36,8 \% dan minoritas tingkat kepuasan yang sangat tidak puas sebanyak $20 \%$. Pada analisa bivariet ini menunjukkan nilai $\rho>\alpha(0.650>0.364)$.
\end{abstract}

Kata Kunci: Pelayanan, kepuasan, KB IUD.

\begin{abstract}
Family planning services aims to improve welfare mother and a son through birth control and controlling population growth. The result of astudy introduction obtained data all acceptors IUD 201586 people. The result of 15 acceptors were satisfied or 5 acceptors were satisfied with the services provided family planning at IUD includes : response midwives, privasy, midwive attitudes, and conseling given. This research used was deskriptif analytic with cross sectional method. The aim of this reseach is to know correlation of the IUD family planning service with the level of satisfaction of IUD acceptors. The population of this research is the people in Sangkrah of IUD acseptors with 30 repondents. Furthermore, this research used non random sampling type with quota sampling method, while it used survey for its instrument. The data analysis was done by spearman ran test on signifikan 5\%. The research results obtained the majority of good service as much as $63,3 \%$, and a minority of service less $20 \%$, while in the majority of level of satisfaction satisfied as much as 36.8\%, very dissatisfied as much as 20\%. On bivariet analysis shows $\rho>\alpha$ $(0650>0.364)$.
\end{abstract}

Keywords: Service, satisfacation, KB IUD. 